Session 2451

\title{
NPDES Phase II Stormwater Rule - An Excellent Opportunity to Get Students Involved in a Service Learning Project
}

\author{
David Pines \\ College of Engineering, Technology, and Architecture \\ University of Hartford
}

\begin{abstract}
The National Pollution Discharge Elimination System (NPDES) Phase II Stormwater Rule was implemented to improve surface water quality by reducing the pollutant discharges by stormwater. The NPDES Phase II Rule requires the development of a stormwater management plan for small municipal separate storm sewer systems (MS4) that includes six minimum control measures. These measures are public education and outreach, public involvement and participation on stormwater impacts, illicit discharge detection and elimination, construction site stormwater runoff control, post-construction stormwater management in new development and redevelopment, and pollution prevention and good housekeeping for municipal operations. In the State of Connecticut, the Department of Environmental Protection (DEP) regulates enforcement through its General Permit for the Discharge of Stormwater from Small MS4s. Because of the emphasis on public involvement, there are numerous opportunities for environmental engineering students to assist in the implementation of a town's stormwater management plan.

As part of the Water Quality Engineering course at the University of Hartford, students performed a service learning project where they monitored stormwater outfall from three residential areas in Bloomfield, CT. The project provided both a meaningful service to the community as well as a relevant learning experience for the student. Specifically, the project supplemented the data that the town is required to collect for the minimum control measure of illicit discharge detection and elimination. Also, the students were required to design and construct an inexpensive automatic mechanical water sampler, investigate the differences between stormwater quality at the three residential sites, analyze the variability in water quality between rain events, and become familiar with the Small MS4 General Permit and the town's stormwater management plan. Presentations by Bloomfield's Town Engineer and an engineer from the CT Department of Environmental Protection (DEP) helped the students better understand the NPDES Phase II Rule.
\end{abstract}




\section{Introduction}

The civil engineering curriculum at the University of Hartford includes a required 4-credit Water Quality Engineering course. Physical, chemical, and biological treatment of water and wastewater are the primary topics covered in this course. The course includes a semester long environmental research group project on a relevant water issue. The projects are selected so that they include most of the following activities: fieldwork, sample analysis, design of a device or small-scale system, bench-scale testing, and computer modeling. At the end of the semester, students make a formal presentation and submit a written report to their sponsors. Examples of previous projects are using an anionic polymer for the recycling of filter backwash water, building a small-scale physical model for analyzing and improving hydraulics of a clearwell, and performing water quality studies on reservoirs and ponds. ${ }^{1,2}$

The challenge for the instructor is to find relevant water service learning projects that can be done by a group of senior civil and environmental engineering students in a one-semester lab course. One source of potential projects is the National Pollution Discharge Elimination System (NPDES) Phase II Stormwater Rule because one of the minimum control measures is public involvement. Therefore, the Phase II Rule provides an added incentive for towns that operate small MS4s to integrate undergraduate environmental engineering projects into their stormwater management plan.

This paper gives a brief description of the benefits of service learning and also provides background information on the NPDES Phase II program requirements and how it is being implemented in the State of Connecticut. Examples are then given on how a town's stormwater management plan can used as a basis for service learning projects that would enhance the educational experience of environmental engineering students. A case study is then presented on a stormwater monitoring service learning project that includes how it was linked to course outcomes and an assessment of the project by students, town engineer, and CT DEP engineers.

\section{Benefits of Service Learning}

Service learning provides a meaningful service to the community as well as a relevant learning experience for the student. The service done by the student is linked to course outcomes and enhances the learning experience that occurs in the classroom. The EPA Service Learning Document ${ }^{3}$ lists the following benefits of service learning:

- Encourages student to learn and develop through active participation in thoughtfully organized service that is conducted in, and meets the needs of, a community

- Helps to foster civic responsibility

- Enhances the academic curriculum

Proceedings of the 2005 American Society for Engineering Education Annual Conference \& Exposition Copyright (C) 2005, American Society for Engineering Education 
- Enhances students' communication, team-building, and critical-thinking skills

- Provides structured time for students to reflect on the service experience

Because of these potential benefits, a service learning component was added to the Water Quality Engineering course in 1999.

\section{National Pollutant Discharge Elimination System Phase II Stormwater Rule}

The 1972 Clean Water Act made it illegal to discharge any pollutant as a point source without authorization by a NPDES permit. Implementation of the Clean Water Act first focused on industrial and municipal sewerage systems, but was amended in 1987 to include the reduction in pollutant discharge by stormwater drainage systems. A two-phase approach was adopted which first aimed at large and medium municipal separate stormwater systems that serve greater than 100,000 people, industrial stormwater, and construction activities that disturbed greater than 5 acres. The Phase I program was implemented in 1990 and required larger cities to develop a stormwater management program. The Phase II Stormwater Rule was published in December 1999 and focused on small Municipal Separate Storm Sewer Systems and small construction activities. The Phase II program includes six Minimum Control Measures (MCMs) that are:

- Public Education and Outreach on Stormwater Impacts

- Public Involvement and Participation

- Illicit Discharge Detection and Elimination

- Construction Site Stormwater Runoff Control

- Post-Construction Stormwater Management in New Development and Redevelopment

- Pollution Prevention and Good Housekeeping for Municipal Operations

In the State of Connecticut, the DEP regulates enforcement of the NPDES Phase II rule through its General Permit for the Discharge of Stormwater from SM4s which was issued on January 9, $2004^{4}$. As part of the general permit, the Town must submit a stormwater management plan (SWMP) that summarizes the best management practices (BMPs) that will be used to achieve the six minimum control measures. Full implementation of the SWMP is required after five years (January 8, 2009) and annual reports must be submitted containing outfall data, best management practice evaluations, and the status of measurable goals. Failures to implement the best management practices are subject to enforcement action as described in the Clean Water Act.

\section{Examples of Potential NPDES Phase II Stormwater Rule Service Learning Projects}

There are numerous opportunities available for environmental engineering students to help towns implement their stormwater management plan. Some of these are volunteer activities while others have the potential of being service learning projects. Whether the project can be considered a service learning project depends on if the objectives of the project also meet the outcomes of the course. Listed in Table 1 are the six MCMs and selected BMPs from the Bloomfield, CT Stormwater Management Plan ${ }^{5}$ are given that have the potential of being the 
topic for a student project. The highlighted BMPs are considered the most promising as service learning projects. For example, students mapping part of a town's drainage system in their GIS class would be good service learning project. However, students working at a town's Household Hazardous Waste Day would be a worthwhile volunteer activity, but likely would not meet the expected outcomes of an environmental engineering course.

Table 1. Best Management Practices* for Minimum Control Measures where Students Could Assist Towns

\begin{tabular}{|l|l|}
\hline \multicolumn{1}{|c|}{ Minimum Control Measure } & \multicolumn{1}{c|}{ Best Management Practice } \\
\hline $\begin{array}{l}\text { Public Education and Outreach on Stormwater } \\
\text { Impacts }\end{array}$ & $\begin{array}{l}\text { Educational Brochures and Fact Sheets } \\
\text { Household Hazardous Waste Days }\end{array}$ \\
\hline Public Involvement and Participation & Organize Public Meetings \\
\hline Illicit Discharge Detection and Elimination & $\begin{array}{l}\text { Town Drainage System Mapping (GIS) } \\
\text { Outfall Inspection and Monitoring } \\
\text { Illicit Discharge Elimination Program (Dye } \\
\text { and Smoke Testing) }\end{array}$ \\
\hline Construction Site Stormwater Runoff Control & Plan Review \\
\hline $\begin{array}{l}\text { Post-Construction Stormwater Management in } \\
\text { New Development and Redevelopment }\end{array}$ & $\begin{array}{l}\text { Identification / Publication of BMPs } \\
\text { Plan Review }\end{array}$ \\
\hline $\begin{array}{l}\text { Pollution Prevention and Good Housekeeping } \\
\text { for Municipal Operations }\end{array}$ & Inventory of Town Facilities and Procedures \\
\hline
\end{tabular}

Best management practices are from the Bloomfield, CT Stormwater Management Plan ${ }^{5}$

\section{Case Study - Residential Stormwater Monitoring Project}

Planning for the Bloomfield Stormwater Monitoring project began in summer 2004 for the fall semester course. Discussions with the town engineer were focused on how a project could help the town implement their stormwater management plan and also meet the Water Quality Engineering course outcomes. From these meetings, it was decided that students could help supplement data required for the MCM of Illicit Discharge Detection and Elimination. Specifically, the student project would help meet the town's BMP of Outfall Inspection and Monitoring. As specified in Bloomfield's stormwater management plan ${ }^{5}$, the goals of this BMP are:

- Conduct dry weather outfall inspections and wet weather sampling and monitoring

- Use consultants, town staff and/or volunteers to perform outfall inspections and assist with wet weather sampling and monitoring

- Establish inspection protocol form, including visual factors and water characteristics

Proceedings of the 2005 American Society for Engineering Education Annual Conference \& Exposition Copyright $@$ 2005, American Society for Engineering Education 
- Conduct dry weather inspections of outfalls for non-stormwater and illicit discharges

- Perform wet weather sampling and testing of outfalls at locations required by the Permit: At least two outfalls apiece will be monitored from areas of primarily industrial development, commercial development, and residential development

The general permit requires that samples be collected from discharges resulting from a storm event that is greater than 0.1 inch in magnitude and that occurs at least 72 hours after any previous storm event of 0.1 inch or greater. In addition, grab samples shall be used for all monitoring and shall be collected during the first six hours of the storm event discharge. Each sample collected shall be analyzed for twelve water quality parameters. Because all twelve water quality parameters could not be easily done in the University of Hartford Environmental Engineering Laboratory (e.g., oil and grease) and that the student engineering project should go beyond only collecting and analyzing water samples, it was decided that the student project would supplement the data collected by a consultant that would specifically meet the requirement of the general permit. With this in mind, the objectives of the student project were to:

- Design and construct an automatic mechanical stormwater sampler

- Collect and analyze water samples at three residential outfalls for three rain events in fall 2004

- Compare how the size of a rainfall event and the duration of time between rainfall events affects stormwater quality

- Compare effect of residential area on stormwater quality

- Calculate the percentage of watershed that was contributing to sample collected for different rainfall intensities

The first goal of the project was for the students to design and construct an automatic mechanical stormwater sampler. The general permit requires that grab samples be collected within the first six hours of a rainfall event of a magnitude greater than $0.1 \mathrm{inch}$. The timing of collecting the sample would be difficult for students if the six-hour time frame occurred during class, on the weekend, or at night. Therefore, the students were required to design, construct, and test a lowcost sampler. This was accomplished by evaluating a commercial model (I-Chem Stormwater Sampler) and also visiting the three residential sites. The students quickly learned that the each site had its own unique characteristics and that there may not be one sampler design that works at all outfalls. Two of the outfalls discharged into a pond that has a water surface elevation greater than the outlet invert under dry weather conditions. Therefore, the stormwater sampler must be positioned so that the inlet of the sampler is above the dry weather water surface elevation. In the other residential area, the outfall discharged onto a ledge that then overfalls into a brook two feet below the ledge. Based on these observations, the students decided to use the purchased commercial stormwater sampler at one of the sites because it could be easily mounted so that the stormwater would overflow into the sampler and their own design at the other two sites.

The students first listed requirements for the stormwater sampler. These included that the sampler must be able to collect a representative water sample without getting clogged and the

\section{Proceedings of the 2005 American Society for Engineering Education Annual Conference \& Exposition} Copyright $@$ 2005, American Society for Engineering Education 
sampler needed to be self sealing after it was full. Two alternative stormwater samplers that were designed, constructed, and tested. Laboratory tests indicated that both samplers worked effectively, but it was decided to use a "PVC pipe sampler" because it required only one piece of rebar to mount at the site.

During fall 2004, samples were collected from three rainfall events that ranged from 0.6 inches to almost 3 inches of precipitation. In addition, a baseflow sample was collected to compare dry weather water quality to "first flush" stormwater quality. For this project, students analyzed stormwater samples for $\mathrm{pH}$, conductivity, hardness, chemical oxygen demand (COD), $\mathrm{UV}_{254}$ absorbance, total suspended solids, turbidity, nitrate, and total phosphorus. Some of the student's conclusions from the water quality data were that each residential area had different stormwater quality depending on the housing density. In one residential area, the average suspended solids and COD concentrations were considered very high because they were greater than the $80^{\text {th }}$ percentile for industrial sites.

To better understand what the water sample collected represented, students analyzed each of the watersheds to determine the percentage of the watershed that was contributing to the sample collected at each of the sites. This was a good exercise because it reinforced the concepts the students had learned in their Water Resources course. Comparison of the percentage of drainage basin illustrated the differences that housing density, size of drainage area, and outfall characteristics had on the sample collected.

From the results of the project, the students recommended that a yearlong study be conducted to determine how seasonal change effect stormwater quality. Because of the small fraction of the watershed that were contributing to the sample collected, it was also recommended that stormwater samples be collected from the catch basins in addition to the outfall. By collecting these samples, it would likely to provide more insight as to what is contributing to the relatively poor water quality at one of the residential outfalls.

The results provided the town useful information on residential stormwater quality and also met course outcomes such as understanding the nature and significant of water pollutants and their components; recording, interpreting, and using field data to provide meaningful information; and making clear, concise, and accurate oral presentations and written reports. The project also demonstrated a number of ABET 2000 outcomes such as applying knowledge of mathematics, science, and engineering; analyzing and interpreting data; designing a system, component, process to meet desired needs; identifying, formulating, and solving engineering problems; and having knowledge of a contemporary issue.

\section{Assessment of Stormwater Monitoring Project}

The tools used to assess the Bloomfield Stormwater Monitoring project were feedback from the students, Bloomfield Town Engineer, and CT DEP engineers who attended the student presentation. In general, the students felt the project was a good learning experience because it was a "real" project. The aspects of project they most enjoyed was designing their own stormwater sampler and getting to see first hand the physical characteristics of various outfalls.

Proceedings of the 2005 American Society for Engineering Education Annual Conference \& Exposition Copyright $@$ 2005, American Society for Engineering Education 
Even though the students were quite nervous at having to present their results to the stormwater group at CT DEP, they felt a sense of accomplishment that eight engineers from CT DEP were interested in attending their presentation and learning about their study. The Bloomfield Town Engineer was especially happy with the data collected by the students because the consultant was not able to collect stormwater samples from any of the industrial, commercial, or residential sites in fall 2004. With the data the students collected, the Town of Bloomfield could report at least some partial data on stormwater quality in their annual report. Finally, the CT DEP employees who work in their stormwater group were impressed with the results of the project and felt that students were very poised during their presentation.

\section{Conclusions}

The Bloomfield Stormwater Monitoring Study was a very successful service learning project. It met the dual objectives of helping the town meet its goal of complying with the general permit for the discharge of stormwater from small MS4s and also was a relevant learning experience for the students. Because the NPDES Phase II Stormwater Rule includes public involvement as one of the minimum control measures, it provides an incentive for towns regulated by this rule to include environmental engineering student projects into their stormwater management plan. In addition to the stormwater monitoring project performed by students from the University of Hartford, there are many other opportunities to incorporate projects relevant to the Phase II Stormwater Rule into environmental courses. For example, one of the projects for next year will be to investigate the effectiveness of detention ponds, constructed wetlands, and commercial devices for treating stormwater.

\section{Acknowledgements}

The author wishes to thank Robert Brinton, Bloomfield, CT Town Engineer, for sponsoring the project and Cheryl Chase, CT DEP, for her presentation to the students on the General Permit for the Discharge of Stormwater from Small Municipal Separate Storm Sewer Systems.

\section{Bibliography}

1. Pines, D. and J. Roberts, "Incorporating a Research Project and a Water Chemistry Laboratory into the Water Quality Engineering Course at the University of Hartford," 2002 ASEE Annual Conference, Albequerque, NM, 2002.

2. Pines,D., "Including Service Learning into the Environmental Engineering Curriculum," 2004 ASEE Annual Conference, Salt Lake City, UT, 2004.

3. USEPA, Service Learning: Education Beyond the Classroom, EPA Document EPA530-K-02-001, September 2002.

4. State of Connecticut, Department of Environmental Projection, "General Permit for the Discharge of Stormwater from Municipal Separate Storm Sewer Systems," January 9, 2004.

5. Town of Bloomfield, CT, "Stormwater Management Plan," July 2004. 


\section{Biographies \\ DAVID PINES}

David Pines is an Assistant Professor of Civil and Environmental Engineering at the University of Hartford. He completed his Ph.D. studies in the Department of Civil and Environmental Engineering at the University of Massachusetts, Amherst in 2000. He is actively involved with student projects sponsored by environmental engineering firms, municipalities, and water utilities. 